\title{
Edwards Wasp Moth, Lymire edwardsii (Grote) (Insecta: Lepidoptera: Arctiidae: Ctenuchinae) ${ }^{1}$
}

\author{
Dale H. Habeck and Frank W. Mead²
}

\section{Introduction}

The caterpillars of Edwards wasp moth frequently cause extensive injury to Ficus trees. Bratley (1929) called it the rubber tree caterpillar because of its injury to rubber trees (Ficus spp.). The immature stages were described by Edwards (1887) and Dyar (1890). Genung (1959) published a comprehensive study on the moth's biology and its control in the Lake Worth, Florida area.

\section{Distribution}

Edwards wasp moth is common throughout southern Florida. It has been reared from as far north as Monticello (Jefferson County), but most records are from south of a line from St. Petersburg to Vero Beach (Kimball 1965). There are continuous generations in south Florida, and caterpillars may be found any month of the year. Distribution records may not be entirely indicative of the true range. Once larvae mature, they crawl about and pupate on walls of buildings as well as on many non-hosts. Therefore, movement of nursery plants with attached pupae may result in its presence in areas well outside its normal range.

\section{Description}

Egg

The egg is spherical and almost translucent; deposited singly or in batches on the underside of the foliage (Genung 1959).

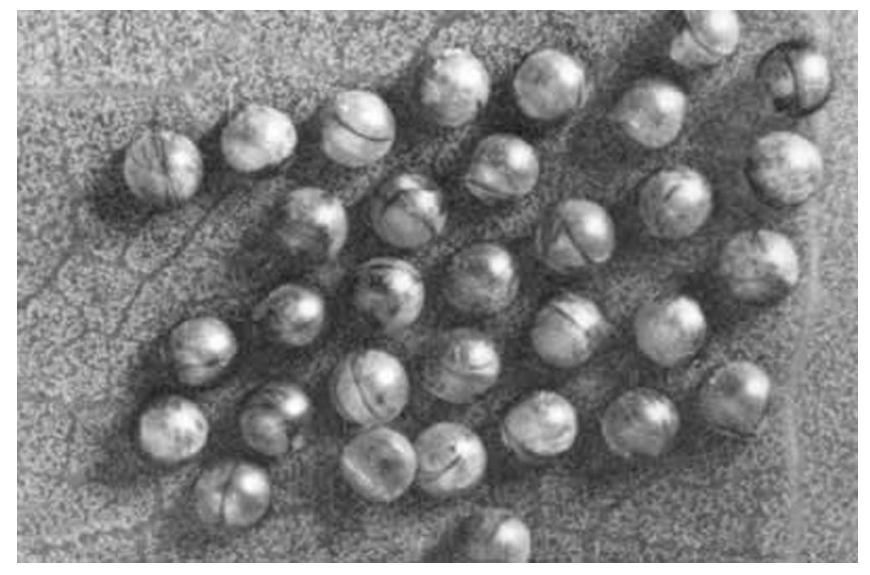

Figure 1. Eggs of the Edwards wasp moth, Lymire edwardsii (Grote). Credits: Division of Plant Industry

1. This document is EENY-182 (originally published as DPI Entomology Circular 234), one of a series of Featured Creatures from the Entomology and Nematology Department, Florida Cooperative Extension Service, Institute of Food and Agricultural Sciences, University of Florida. Published: December 2000. This document is also available on Featured Creatures Website at http://creatures.ifas.ufl.edu. Please visit the EDIS Website at http://edis.ifas.ufl.edu.

2. Dale H. Habeck, professor, Entomology and Nematology Department, University of Florida, Gainesville, and Frank W. Mead, Department of Agriculture and Consumer Services, Division of Plant Industry, Gainesville, FL.

The Institute of Food and Agricultural Sciences (IFAS) is an Equal Employment Opportunity - Affirmative Action Employer authorized to provide research, educational information and other services only to individuals and institutions that function without regard to race, creed, color, religion, age, disability, sex, sexual orientation, marital status, national origin, political opinions or affiliations. For information on obtaining other extension publications, contact your county Cooperative Extension Service office. Florida Cooperative Extension Service / Institute of Food and Agricultural Sciences / University of Florida / Larry R. Arrington, Interim Dean 


\section{Larva}

The mature larva is pale yellow with an irregularly broken wide, mid-dorsal, brown stripe. The entire body is covered with plumose whitish to yellow setae arising from verrucae (warts). All setae are unicolorous except for a mid-dorsal tuft of brown setae on the first abdominal segment. The head capsule is reddish brown with a dark area on each side of the adfrontal suture. The frons, clypeus, and labrum are white, and the mandibles are brown. The distinct coloration of the head permits easy recognition of the larvae.

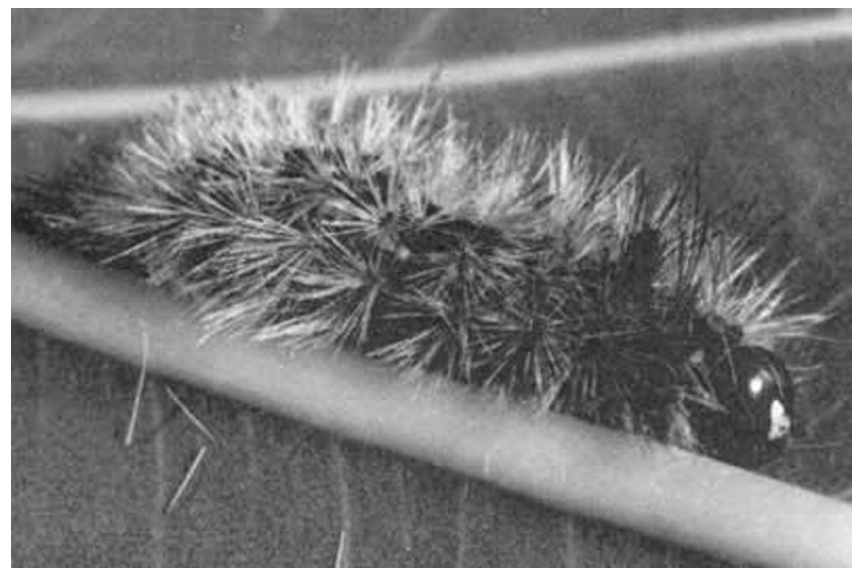

Figure 2. Larva of the Edwards wasp moth, Lymire edwardsii (Grote). Credits: Division of Plant Industry

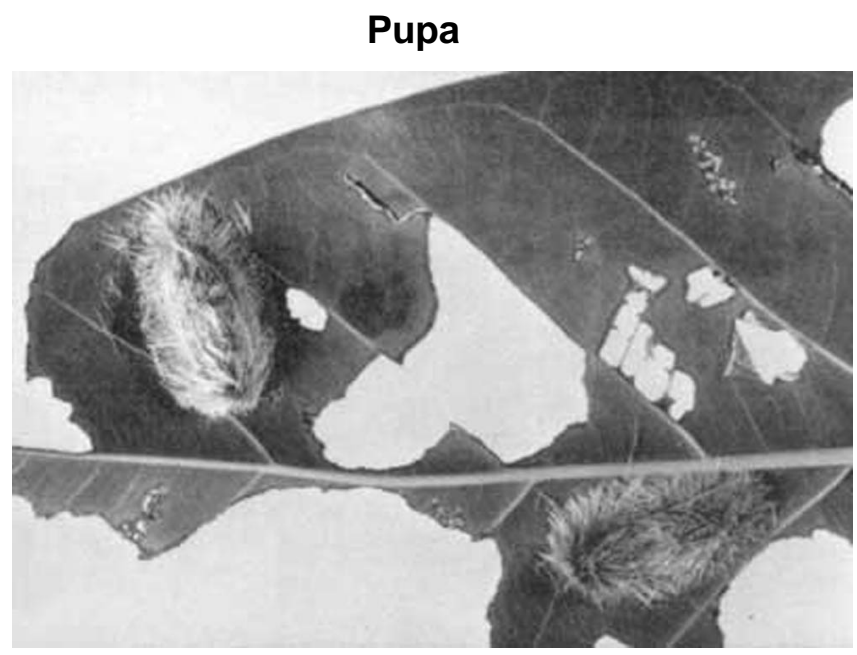

Figure 3. Pupae of the Edwards wasp moth, Lymire edwardsii (Grote), on leaf of damaged Ficus sp. Credits: Division of Plant Industry

The pupa is brown, enclosed in a thin flimsy cocoon composed primarily of the broken off setae of the caterpillar. Cocoons are usually attached to a wall, tree, or other object.

\section{Adult}

Size varies, but the wingspan usually ranges from 35 to $40 \mathrm{~mm}$. The wings and thorax are bluish gray. The abdomen is blue dorsally and white ventrally. The prothorax and head are orange-yellow ventrally. Dorsally and laterally the posterior portion of the head and anterior margin of the prothorax are orange-yellow. The antennae are pectinate.

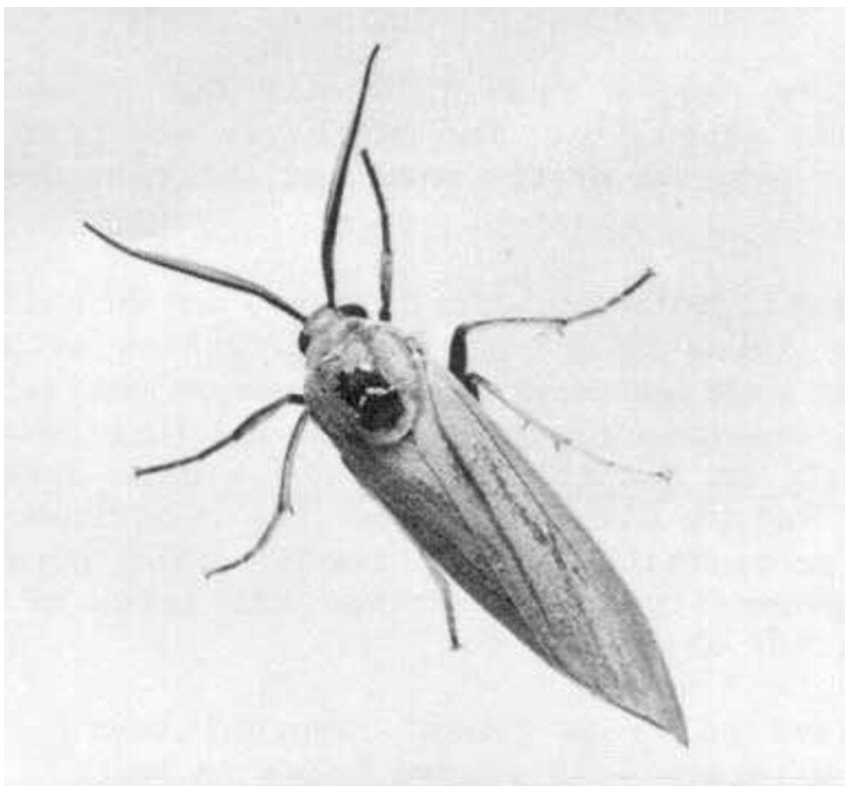

Figure 4. Adult Edwards wasp moth, Lymire edwardsii (Grote). Credits: Division of Plant Industry

\section{Host Plants}

As far as known, the caterpillars feed only on Ficus spp., and the following host species have been recorded: altissima Blume, aurea Nutt., auriculata Lour., benghalensis L., benjamina L., continifolia HBK, elastica Roxb. ex Hornem, lyrata Warb., retusa L. and rubiginosa Desf. ex Venten.

More than a dozen other plant species have been recorded as larval hosts, but these reports apparently represent mature larvae looking for pupation sites as well as those which have become dislodged from their host plant and are searching for food.

\section{Economic Importance}

The caterpillars can be quite destructive to Ficus trees. They may feed on leaf margins or chew irregularly shaped holes in the leaves. Their habit of spinning cocoons on the walls of houses can be a 
nuisance to homeowners. Genung (1959) reported up to 35 pupae, prepupae, and abandoned cocoons and pupal cases per square foot on some buildings.

\section{Survey and Detection}

Check damaged Ficus leaves for fuzzy, whitish yellow caterpillars with a conspicuous white triangle on the front of the head. The brown pupae are in a flimsy cocoon attached to leaves, trunks, or walls of buildings near Ficus trees.

\section{Natural Enemies}

Parasitization of caterpillars and/or pupae is very heavy especially in late summer and fall. Bratley (1929) reported $96 \%$ parasitization by the tachinid fly, Phorocera claripennis Macquart (now in Euphorocera), and the chalcid wasp, Brachymeria robusta (Cresson). Genung (1959) reared two chalcid wasps, Brachymeria robusta (Cresson) and $B$. ovata (Say) and a tachinid fly, Achaetoneura aletiae (Riley) (now in Lespesia) from pupae and a scelionid, Telenomus sp., from the eggs. Up to 89.5 $\%$ of larvae and pupae and $40 \%$ of eggs were parasitized in July. Genung also found three species of pentatomids (stink bugs), Podisus maculiventris (Say), P. mucronatus Uhler, and Euthyrhynchus floridanus (L.), preying on the caterpillars.

\section{Management}

Edwards wasp moth caterpillars may be controlled with Bacillus thuringiensis which is available in several formulations from several companies. Instructions on the package should be followed. This insecticide will provide control without leaving chemical residues or harmful effects on parasites and predators.

\section{Selected References}

Bratley, H.E. 1929. Notes on Lymire edwardsii Grote, the rubber tree caterpillar. Florida Entomologist 13: 42.

Dyar, H.G. 1890. Preparatory stages of Syntomeida epilais Walker and Scepsis edwardsii Grote. Insect Life 2: 360-362.
Edwards, Henry. 1887. Early stages of some North American Lepidoptera. Ent. Amer. 3: 161-171.

Genung, W.G. 1959. Notes on the syntomid moth Lymire edwardsii (Grote) and its control as a pest of Ficus in south Florida. Florida Entomologist 42: 39-42.

Kimball, C.P. 1965. The Lepidoptera of Florida. Florida Dept. Agric., Div. Plant Ind., Arthropods of Florida and Neighboring Land Areas 1: 1-363. 